\title{
Dopasowanie systemu implantu ślimakowego - podstawy teoretyczne
}

\section{Fitting of cochlear implant system - theoretical basis}

\author{
Aleksandra Pieczykolan ${ }^{1}$, Marika Kruszyńska ${ }^{1}$, Tomasz Wiśniewski ${ }^{1}$, Artur Lorens ${ }^{1}$, \\ Henryk Skarżyński² \\ ${ }^{1}$ Instytut Fizjologii i Patologii Słuchu, Światowe Centrum Słuchu, Zakład Implantów i Percepcji Słuchowej, \\ Warszawa/Kajetany \\ ${ }^{2}$ Instytut Fizjologii i Patologii Słuchu, Warszawa/Kajetany
}

\begin{abstract}
Adres autora: Aleksandra Pieczykolan, Światowe Centrum Słuchu, Zakład Implantów i Percepcji Słuchowej, ul. Mokra 17, Kajetany, 05-830 Nadarzyn, e-mail: a.pieczykolan@ifps.org.pl
\end{abstract}

\section{Streszczenie}

\begin{abstract}
Wstęp: System implantu ślimakowego poprzez elektrostymulację zakończeń nerwu słuchowego pozwala na przywrócenie percepcji dźwięku u osób z całkowitą lub częściową głuchotą. Z biegiem lat zmianie ulegały nie tylko kryteria kwalifikacji do wszczepienia implantu ślimakowego, lecz także sam proces dopasowania systemu implantu. Początkowo dopasowanie było rozumiane jako ustawienie minimalnych i maksymalnych poziomów stymulacji elektrycznej, jednak postęp technologiczny oraz rosnąca wiedza na temat implantów doprowadziły do zmiany w podejściu do zagadnienia dopasowania tego systemu.
\end{abstract}

Cel: Celem pracy było przedstawienie podstaw teoretycznych dotyczących dopasowania systemu implantu ślimakowego, a także analiza zebranych metod jego dopasowania prezentowanych w literaturze.

Materiał i metoda: Niniejsza praca powstała na podstawie przeglądu literatury na temat dopasowania systemu implantu ślimakowego. Wstępnie do analizy zakwalifikowano 530 pozycji literaturowych. Po selekcji artykułów usunięto duplikaty, pozycje w językach innych niż polski lub angielski, prace dotyczące strategii kodowania sygnałów wykorzystywanych w procesorach mowy, wyników badań osób korzystających z implantów słuchowych itp. Ostatecznie do przeglądu zakwalifikowano 44 prace.

Wyniki: Na postawie analizy zakwalifikowanych do przeglądu artykułów sporządzono zestawienie procedur dopasowania implantu ślimakowego z uwzględnieniem celu, zakresu działania oraz grupy pacjentów, której dedykowane było dane podejście. Zdaniem około $60 \%$ specjalistów proces dopasowania systemu implantu ślimakowego ma charakter peryferyjny, około $20 \%$ prezentowanych w niniejszej pracy definicji dotyczy podejścia centralnego, w pozostałych $20 \%$ publikacji zostało przedstawione podejście funkcjonalne.

Wnioski: Jak dotąd nie udało się stworzyć jednolitego modelu opieki nad pacjentem implantowanym. Obecnie najbardziej optymalne wydaje się podejście oparte na funkcjonalnym modelu niepełnosprawności, w którym to dopasowanie systemu implantu ślimakowego rozumiane jest jako zminimalizowanie negatywnych skutków niepełnosprawności słuchowej.

Słowa kluczowe: dopasowanie systemu implantu ślimakowego • audiologia • zaburzenia słuchu

Abstract

Introduction: Electrical stimulation of auditory nerve with cochlear implant allows to restore sound perception in patients with partial or complete deafness. Over the years the eligibility criteria and fitting procedures have been subject to changes. Initially, programming was understood in terms of setting of minimum and maximum levels of electric stimulation, but as the technology of cochlear implants and the knowledge about them started to develop, the fitting procedures have been approached from a different standpoint.

Aim: The aim of this study was to present the theoretical framework related to programming of cochlear implant and to analyze fitting methods described in literature. 
Material and methods: This study was prepared as a result of literature review. The preliminary analysis covered 530 works. After the selection of the articles, some of the works were removed, including the duplicates, non-Polish and non-English works, patients' results as well as works on coding stategies used in speech processors. Ultimately, 44 pieces of literature were qualified.

Results: The analysis of classified articles allowed to juxtapose the procedures of cochlear implant fitting, with respect to their purpose, functioning and the groups of patients whom a given data approach was dedicated to. According to almost $60 \%$ of authors, any fitting procedure should be considered in terms of the peripheral approach, whereas $20 \%$ of articles covered in this publication include it in the central approach, and another $20 \%$ - in the functional approach.

Conclusions: Thus far, no single and universal model of patient's care after implantation. Currently, has been developed the most optimal one seems to be the functional approach. The framework is based on the functional model of disability in which the main goal of a fitting procedure is to minimalize the negative effects of hearing disorders.

Key words: fitting of cochlear implant system • audiology $\bullet$ hearing disorders

\section{Wstęp}

Implant ślimakowy jest to rodzaj elektronicznej protezy słuchowej, umożliwiającej percepcję dźwięku u osób z całkowitą lub częściową głuchotą [1]. Dzięki bezpośredniej stymulacji elektrycznej zakończeń nerwu słuchowego możliwe jest zastąpienie funkcji uszkodzonego narządu receptorowego ślimaka [2]. System implantu ślimakowego składa się z dwóch części - wewnętrznej, umieszczanej operacyjnie w niszy kości skroniowej pod płatem skórnym oraz zewnętrznej, noszonej za uchem [1].

Część wewnętrzna składa się z: odbiornika i stymulatora elektrycznego, czyli tzw. kapsuły implantu, oraz elektrody wewnątrzślimakowej. Natomiast część zewnętrzną stanowi cyfrowy procesor mowy $[1,3,4]$. Wszystkie wyżej wymienione części implantu zostały przedstawione na rycinie 1 .

Zasada działania implantu ślimakowego opiera się na odpowiedniej stymulacji elektrycznej zakończeń nerwu słuchowego. Funkcja komórek słuchowych, czyli zamiana dźwięku na impulsy neuronalne, zostaje zastąpiona przez system implantu. Mikrofon procesora mowy odbiera sygnał akustyczny, a następnie przekształca go w analogowy sygnał elektryczny, który podawany jest na wejście przetwornika analogowo-cyfrowego i zamieniany na sygnał cyfrowy, który to z kolei zostaje przetworzony na bodziec elektryczny, a następnie za pośrednictwem fal radiowych przesłany przez transmiter do części wewnętrznej implantu [2].

Pierwszy na świecie program leczenia głuchoty za pomocą systemu implantu ślimakowego powstał na początku lat 70. ubiegłego wieku w USA. Zapoczątkował go W. House, wykorzystując system jednokanałowy $3 \mathrm{M}$. Jednak z uwagi na wadliwość tego sytemu został on szybko wycofany z praktyki klinicznej [3]. W 1973 r. podobny program w Europie prowadzili C. H. Chouard (Paryż) i K. Burian (Wiedeń) [4,5]. W Polsce pierwszą operację wszczepienia implantu ślimakowego przeprowadził H. Skarżyński w 1992 r. [2].

Zgodnie z początkowymi wskazaniami do operacji wszczepienia implantu kwalifikowane były osoby dorosłe z całkowitą głuchotą. Ponadto pierwsi pacjenci, u których stosowano implanty ślimakowe, byli użytkownikami systemów jednokanałowych, umożliwiających odbiór podstawowych wrażeń słuchowych. Zaledwie w 1 na 20 przypadków

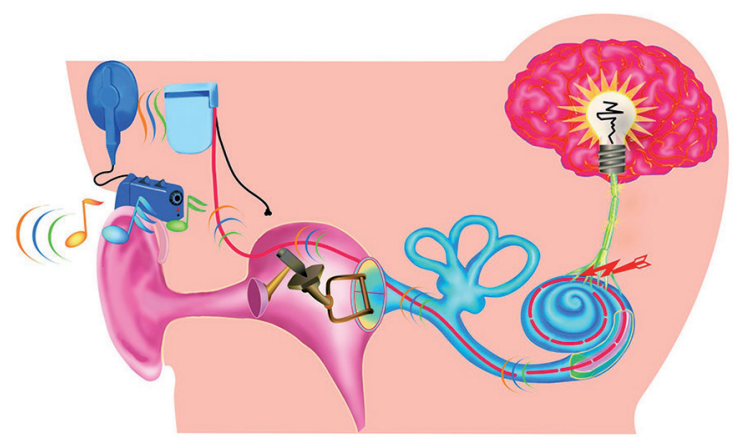

Rycina 1. System implantu ślimakowego

Figure 1. Cochlear implant system

możliwy był bardzo ograniczony odbiór mowy [6]. Rewolucyjne okazały się systemy wielokanałowe, których skuteczność potwierdziły dobre wyniki osiągane przez pacjentów w testach rozumienia mowy. Dzięki zastosowaniu systemów wielokanałowych wzrosła liczba użytkowników implantu ślimakowego. Rozpoczęto również wszczepianie implantów ślimakowych dzieciom z wrodzonym głębokim niedosłuchem [5-10].

Postęp techniczny oraz udokumentowana w licznych pracach wysoka skuteczność interwencji medycznej z wykorzystaniem systemu implantu ślimakowego spowodowały dalsze rozszerzenie kryteriów kwalifikacji. Do operacji wszczepiania implantu kwalifikowano osoby, którym aparaty słuchowe umożliwiały rozumienie mowy jedynie w bardzo ograniczonym stopniu [8]. Dzięki nowym technikom chirurgicznym możliwe jest zachowanie resztek słuchowych, a co za tym idzie połączenie stymulacji elektryczno-akustycznej [11]. Poszerzenie kryteriów kwalifikacji oraz wprowadzenie nowych metod leczniczo-rehabilitacyjnych dało możliwość stosowania implantów w różnych nowych grupach docelowych.

W 2002 r. prof. H. Skarżyński przeprowadził pierwszą $\mathrm{w}$ świecie operację wszczepienia implantu ślimakowego u pacjenta z częściową głuchotą, rozpoczynając tym samym program leczenia częściowej głuchoty (ang. Partial Deafness Treatment, PDT). Pacjenci ci charakteryzują się normalnym lub nieznacznie podwyższonym progiem słyszenia w zakresie częstotliwości niskich i średnich oraz znacznym bądź głębokim ubytkiem słuchu w zakresie częstotliwości wysokich [12,13]. Dzięki zachowaniu, po 
operacji, słuchu naturalnego dla niskich częstotliwości możliwe jest uzupełnienie go przez słuch elektryczny uzyskiwany za pośrednictwem implantu. Według licznych publikacji, wykorzystanie naturalnego, akustycznego słuchu pozwala m.in. na uzyskanie lepszych wyników rozumienia mowy zarówno w ciszy, jak i w warunkach utrudnionych.

Wśród użytkowników implantu ślimakowego są także osoby korzystające z systemów implantów obuusznie. Głównym celem implantacji bilateralnej jest poprawa lokalizacji dźwięku oraz lepsze rozumienie mowy w hałasie [14-16]. Stosunkowo najmłodszą z grup docelowych są osoby z jednostronną głuchotą (ang. Single Sided Deafness, SSD) [17]. Pacjenci ci mają trudności z lokalizacją źródła dźwięku oraz rozumieniem mowy w hałasie. Motywacją do podjęcia decyzji o implantacji są także niekiedy uporczywe szumy uszne.

Wraz z rozwojem technologicznym w dziedzinie implantów ślimakowych zmieniały się także metody dopasowania tego systemu. Początkowo dopasowanie jednokanałowych systemów implantów polegało na kształtowaniu charakterystyki amplitudowo-częstotliwościowej analogowego toru przetwarzania dźwięku na analogowy bodziec elektryczny. W tym celu wykonywano badanie psychofizyczne, mierząc próg elektrycznie wywołanego słyszenia, poziomy bodźca odpowiadające komfortowemu słyszeniu oraz progowi bólu. Stosowanymi bodźcami były przebiegi sinusoidalne o częstotliwościach oktawowych w zakresie od $64 \mathrm{~Hz}$ do $4000 \mathrm{~Hz}$ [18]. Wraz z wprowadzeniem systemów wielokanałowych dopasowanie systemu polegało na określeniu parametrów stymulacji impulsowej takich jak częstość stymulacji, szerokość impulsu stymulującego, kształt funkcji kompresji sygnału, oraz poziomów stymulacji odpowiadających progowi słyszenia i poziomowi komfortowego słyszenia osobno dla każdego kanału przetwarzania sygnału. Istotny wpływ na dopasowanie ma wartość impedancji elektrycznej elektrod wewnątrzślimakowych, od której zależy dobór odpowiednich poziomów prądu stymulacji [19]. Obecnie przy każdej wizycie specjalista zajmujący się doborem parametrów stymulacji elektrycznej dokonuje pomiaru impedancji elektrod oraz porównuje jego wynik z poprzednimi badaniami.

W trakcie dopasowania systemów implantów wykonuje się również badania obiektywne będące pomiarami biofizycznymi. Zaletą obiektywnych metod diagnostycznych jest fakt, że nie wymagają one udziału pacjenta, dlatego mogą być $\mathrm{z}$ powodzeniem wykorzystywane u małych dzieci [20]. Przykładami takich badań są: pomiar elektrycznie wywołanych słuchowych odpowiedzi pnia mózgu (ang. Electrically Evoked Auditory Brainstem Response, EABR), pomiar elektrycznie wywołanego odruchu z mięśnia strzemiączkowego (ang. Electrically Evoked Stapedius Responses Thresholds, ESRT) czy pomiar elektrycznie wywołanego potencjału czynnościowy nerwu słuchowego (ang. Electrically Evoked Compound Action Potential of the Auditory Nerve, ECAP) [20].

Jednocześnie coraz częściej w procesie dopasowania procesora wykorzystywano subiektywne badania audiologiczne, wymagające współpracy ze strony badanego. Wykonuje się je warunkach odsłuchu przez system implantu ślimakowego, a należą do nich:
- audiometria w polu swobodnym (AWP),

- audiometria słowna (AS),

- skalowanie głośności (WHF),

- lokalizacja.

Wyniki badań audiologicznych służą do weryfikacji poprawności doboru parametrów stymulacji elektrycznej. Autorzy zajmujący się zagadnieniem podkreślają także, że ważną rolę w kontroli poprawności dopasowania systemu implantu ślimakowego odgrywa subiektywna ocena korzyści słuchowych i jakości życia związanej ze zdrowiem $[21,22]$.

We współczesnych wielokanałowych, cyfrowych systemach implantu ślimakowego proces dopasowania systemu polega na odpowiednim zaprogramowaniu procesora mowy (części zewnętrznej). Korzystając z komputera PC oraz specjalistycznego oprogramowania i interfejsu, parametry impulsowej stymulacji elektrycznej wpisuje się do wewnętrznej pamięci procesora mowy. Zbiór parametrów stymulacji, do których należą poziomy prądu lub poziomy ładunku elektrycznego odpowiadające progowi słyszenia oraz wrażeniu głośnego i komfortowego słyszenia, liczba aktywnych elektrod, częstość stymulacji, strategia kodowania sygnału, kształt funkcji kompresji, określany jest jako mapa pacjenta [2].

Na skuteczność procesu dopasowania wpływ wywiera wiele czynników, między innymi: przyczyna niedosłuchu, czas, jaki minął od momentu utraty słuchu do operacji wszczepienia implantu. Ważną rolę odgrywają również właściwości biofizyczne złącza elektroda-komórki nerwowe, które zależne są od:

- budowy anatomicznej ślimaka (jego wymiaru i kształtu), - elektrycznych właściwości tkanek,

- budowy wiązki elektrod (wymiarów i kształtu kontaktów elektrycznych, długości wiązki),

- ilości przetrwałych włókien nerwowych,

- wzajemnego położenia włókien i kontaktów elektrod [23].

Wszystkie z wymienionych powyżej cech są indywidualne dla każdego pacjenta, dlatego właśnie każdy przypadek jest inny. W związku z tym niezwykle ważne jest, by uwzględnić to podczas dopasowania systemu implantu ślimakowego [18]. Ponadto proces dopasowania systemu implantu ślimakowego musi uwzględniać pewną specyfikę danej grupy docelowej.

Celem niniejszej pracy było przedstawienie podstaw teoretycznych dotyczących dopasowania systemu implantu ślimakowego. Na podstawie literatury zebrano opisy dopasowania systemu implantu. Następnie wyodrębniono cele, zakres działania oraz grupy docelowe opisane w kontekście poszczególnych realizacji klinicznych procedur dopasowania systemu implantu. Na podstawie wyszukanych opisów dokonano klasyfikacji opisanych w literaturze procesów dopasowania systemów implantów na te, w których stosowane są tzw. podejścia peryferyjne, centralne oraz funkcjonalne.

\section{Materiał i metoda}

Poniższa praca powstała jako wynik przeglądu literaturowego dotyczącego dopasowania systemów implantów 


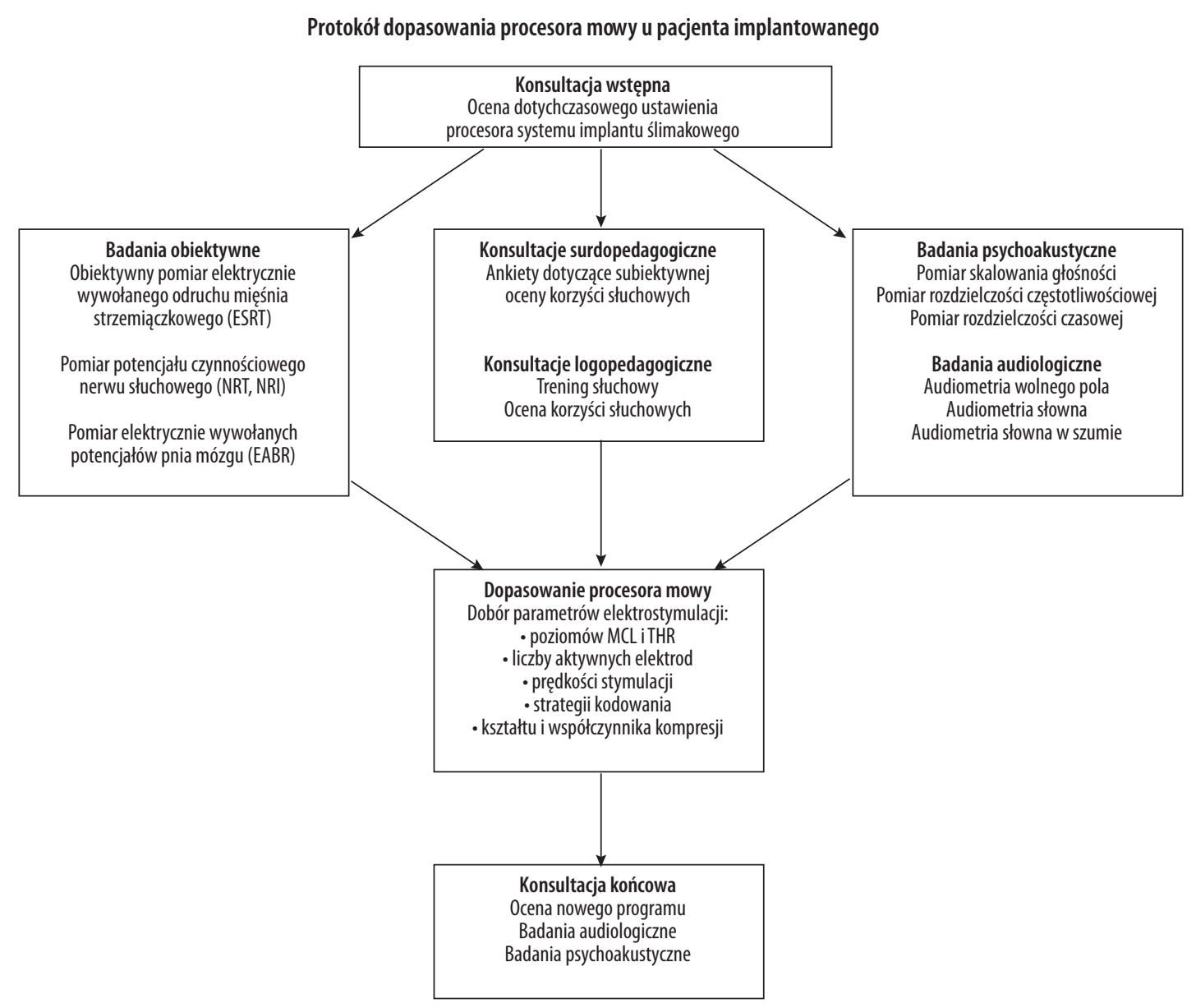

Rycina 2. Procedura dopasowania procesora mowy. Źródło: Skarżyński H, Piotrowska A, Lorens A. Wszczepy ślimakowe. W: Śliwińska-Kowalska M, red., Audiologia kliniczna. Mediton, 2005; 429-42

Figure 2. The procedure of speech procesor fitting. Source: Skarżyński H, Piotrowska A, Lorens A, Wszczepy ślimakowe, In: Śliwińska-Kowalska M, ed., Audiologia kliniczna. Mediton, 2005; 429-42

ślimakowych. Źródłami danych zamieszczonych w tym artykule są: wyszukiwarki medyczne, tj. PubMed i Ovid ( $\mathrm{n}=490)$, część publikacji została polecona przez eksperta $(n=31)$, pozostałe prace pochodziły $\mathrm{z}$ innych źródeł $(\mathrm{n}=9)$, tj. pism naukowych: „Nowa Audiofonologia”, „Otorynolaryngologia”, strony internetowej US Food and Drug Administration.

Materiałów naukowych szukano, używając następujących słów kluczowych:

- cochlear implant fitting [24-27],

- cochlear implant programming [18,28,29],

- cochlear implant mapping [16],

- cochlear implant tuning/switch on [19,30].

Poniżej przedstawiono zapytania formułowane w automatycznych wyszukiwarkach bazodanowych PubMed i Ovid:

1. (cochlear implant[Title]) AND fitting[Title]

2. (cochlear implant[Title]) AND programming[Title]

3. (cochlear implant[Title]) AND mapping[Title]

4. (cochlear implant[Title]) AND settings[Title]

5. (cochlear implant[Title]) AND switch on[Title]

6. (sound processor[Title]) AND settings[Title]

7. (bilateral[Title]) AND cochlear implant[Title]

8. (partial deafness[Title]) AND cochlear implant[Title]
9. (cochlear implant[Title]) AND children[Title]

10. (cochlear implant[Title]) AND adults[Title]

11. (bilateral [Title]) AND cochlear implant[Title]

12. (cochlear implant [Title] AND partial deafness [Title]

Strony internetowe, z których korzystano podczas pisania niniejszej pracy:

1. http://www.kardiologiainwazyjna.pl/mod/archiwu$\mathrm{m} / 8367$, implanty,\%C5\%9Blimakowe,zasada.html

2. https://www.nidcd.nih.gov/health/cochlear-implants

3. $h t t p: / / w w w . f d a . g o v / M e d i c a l D e v i c e s / P r o d u c t-$ sandMedicalProcedures/ImplantsandProsthetics/ CochlearImplants/

4. http://www.nowaaudiofonologia.pl/

5. http://www.mediton.pl/PL/czasopisma/otorynolaryngologia/archiwum.html

Wstępnie do analizy zakwalifikowano 530 pozycji literaturowych. Po selekcji artykułów usunięto duplikaty, pozycje w językach innych niż polski lub angielski, prace dotyczące strategii kodowania sygnałów wykorzystywanych w procesorach mowy, wyników badań osób korzystających z implantów słuchowych itp. Ostatecznie do przeglądu zakwalifikowano 44 prace (rycina 2). 
Tabela 1. Procedury dopasowania implantu ślimakowego przedstawione w literaturze z podziałem na cel, zakres działania i grupy pacjentów

Table 1. The procedures of cochlear implant fitting described in the literatute including their purpose, functionig and the groups of patients

\begin{tabular}{|c|c|c|c|c|}
\hline Autorzy & Definicja & Cel & Zakres działania & Grupa pacjentów \\
\hline \multicolumn{5}{|c|}{ Podejście peryferyjne } \\
\hline $\begin{array}{l}\text { Boyd PJ. Effects of } \\
\text { programming threshold } \\
\text { and maplaw settings on } \\
\text { acoustic thresholds and } \\
\text { speech discrimination } \\
\text { with the MED-EL COMBI } \\
40+\text { cochlear implant. } \\
\text { (2006) }\end{array}$ & $\begin{array}{l}\text { Głównym zadaniem } \\
\text { w programowaniu procesora } \\
\text { mowy implantu ślimakowego } \\
\text { jest ustawienie dynamiki } \\
\text { pobudzenia dla każdej } \\
\text { elektrody. Ustawienie } \\
\text { obejmuje zazwyczaj } \\
\text { pomiary psychofizyczne } \\
\text { progu elektrycznego oraz } \\
\text { górnych poziomów tolerancji, } \\
\text { poprzez użycie krótkich } \\
\text { tonów generowanych } \\
\text { przez oprogramowanie } \\
\text { komputerowe. }\end{array}$ & $\begin{array}{l}\text { Zapewnienie } \\
\text { optymalnego } \\
\text { poziomu głośności } \\
\text { na podstawie } \\
\text { zakresu poziomów } \\
\text { wejściowych. }\end{array}$ & $\begin{array}{l}\text { Programowanie, } \\
\text { opieka audiologiczna } \\
\text { oraz w późniejszym } \\
\text { czasie pomiary } \\
\text { obiektywne. }\end{array}$ & $\begin{array}{l}\text { Osoby dorosłe } \\
\text { z niedosłuchem } \\
\text { postlingwalnym. }\end{array}$ \\
\hline $\begin{array}{l}\text { Vaerenberg B, Smits C, } \\
\text { Ceulaer GD. Cochlear } \\
\text { implant programming: } \\
\text { a global survey on the } \\
\text { state of the art. (2014) }\end{array}$ & $\begin{array}{l}\text { Główny nacisk kładzie się na } \\
\text { ustawienie maksymalnych } \\
\text { i w mniejszym stopniu } \\
\text { minimalnych poziomów } \\
\text { stymulacji na każdej } \\
\text { elektrodzie. Często poziomy } \\
\text { te są wyznaczane dla kilku } \\
\text { elektrod, a następnie ich } \\
\text { wartości ustawiane są także } \\
\text { na innych elektrodach. } \\
\text { Proces dopasowania opiera } \\
\text { się głównie na subiektywnej } \\
\text { ocenie głośności użytkownika } \\
\text { implantu. W mniejszym } \\
\text { stopniu wykorzystuje się } \\
\text { wyniki badań AT i AS. Pomiary } \\
\text { obiektywne odgrywają } \\
\text { niewielką rolę w ustawieniach } \\
\text { MAP pacjenta. }\end{array}$ & $\begin{array}{l}\text { Ustawienie } \\
\text { parametrów } \\
\text { stymulacji, które } \\
\text { zapewnią, że } \\
\text { wzór elektryczny } \\
\text { generowany przez } \\
\text { urządzenie umożliwi } \\
\text { optymalne rozumienie } \\
\text { mowy. }\end{array}$ & $\begin{array}{l}\text { Programowanie, } \\
\text { opieka audiologiczna } \\
\text { (w tym badania } \\
\text { obiektywne). }\end{array}$ & Dzieci i dorośli. \\
\hline $\begin{array}{l}\text { Henkina Y, Kaplan- } \\
\text { Neemana R, Muchnik } \\
\text { Ch. Changes over time } \\
\text { in electrical stimulation } \\
\text { levels and electrode } \\
\text { impedance values } \\
\text { in children using the } \\
\text { Nucleus } 24 \mathrm{M} \text { cochlear } \\
\text { implant. (2003) }\end{array}$ & $\begin{array}{l}\text { Dopasowanie procesora } \\
\text { polega na ustawieniu } \\
\text { minimalnych i maksymalnych } \\
\text { poziomów stymulacji } \\
\text { na podstawie wyników } \\
\text { subiektywnej oceny progu } \\
\text { styszenia i komfortowego } \\
\text { poziomu styszenia. }\end{array}$ & $\begin{array}{l}\text { Utworzenie } \\
\text { optymalnego zakresu } \\
\text { dynamicznego } \\
\text { pobudzenia, } \\
\text { który umożliwi } \\
\text { użytkownikowi } \\
\text { implantu skuteczną } \\
\text { komunikację. } \\
\text { Oznacza to, że ciche } \\
\text { dźwięki powinny być } \\
\text { rozróżniane, normalna } \\
\text { mowa zrozumiała, } \\
\text { a głośne dźwięki } \\
\text { akceptowalne. }\end{array}$ & $\begin{array}{l}\text { Programowanie } \\
\text { procesora mowy. }\end{array}$ & $\begin{array}{l}\text { Pacjenci w wieku } \\
\text { 4-68 lat, } \\
\text { zaimplantowani } \\
\text { 12-kanałowym } \\
\text { COMBI 40+. }\end{array}$ \\
\hline $\begin{array}{l}\text { Mertes J, Chinnici J. } \\
\text { Timing of cochlear } \\
\text { implantation and } \\
\text { parents' global ratings } \\
\text { of children's health and } \\
\text { development. (2006) }\end{array}$ & $\begin{array}{l}\text { Implanty ślimakowe są } \\
\text { zazwyczaj ustawiane } \\
\text { dla każdego pacjenta } \\
\text { indywidualnie na podstawie } \\
\text { ich wrażeń słuchowych } \\
\text { w odpowiedzi na bodziec } \\
\text { elektryczny. Pierwsze } \\
\text { programy, tzw. MAPY, } \\
\text { ustawiane są po około } 4 \\
\text { tygodniach po operacji. } \\
\text { Program tworzony jest } \\
\text { poprzez ustawienie wartości } \\
\text { progowych (T-levels) oraz } \\
\text { poziomu komfortowego } \\
\text { słyszenia (M lub C-levels). }\end{array}$ & Satysfakcja pacjenta & $\begin{array}{l}\text { Programowanie, } \\
\text { opieka audiologiczna. }\end{array}$ & Dzieci. \\
\hline
\end{tabular}


Pieczykolan A i wsp.: Dopasowanie systemu implantu ślimakowego...

\begin{tabular}{|c|c|c|c|c|}
\hline Autorzy & Definicja & Cel & Zakres działania & Grupa pacjentów \\
\hline $\begin{array}{l}\text { Zwolan T A., O'Sullivan } \\
\text { MB, Fink NE. Electric } \\
\text { charge requirements } \\
\text { of pediatric cochlear } \\
\text { implant recipients } \\
\text { enrolled in the } \\
\text { childhood development } \\
\text { after cochlear } \\
\text { implantation study } \\
\text { (2008). }\end{array}$ & $\begin{array}{l}\text { Do programowania procesora } \\
\text { mowy implantu ślimakowego } \\
\text { wykorzystywane są badania } \\
\text { psychofizyczne, które } \\
\text { wykonuje się podczas wizyty. } \\
\text { Należą do nich między innymi: } \\
\text { 1) wartości progowe (T-levels), } \\
\text { czyli najcichszy dźwięk } \\
\text { postrzegany przez pacjenta } \\
\text { podczas stymulacji na danej } \\
\text { elektrodzie; } \\
\text { 2) wartości komfortowego } \\
\text { słyszenia (M/C-levels), czyli } \\
\text { wartości, dla których głośne } \\
\text { dźwięki są na akceptowalnym } \\
\text { poziomie. } \\
\text { Do ustawień używa } \\
\text { się specjalistycznego } \\
\text { oprogramowania, które } \\
\text { umożliwia wgranie tych } \\
\text { parametrów na tzw. MAPĘ } \\
\text { pacjenta - program. Wartości } \\
\text { te mogą być oszacowane } \\
\text { przy wykorzystaniu metod } \\
\text { behawioralnych, obiektywnych } \\
\text { bądź obydwu z nich. }\end{array}$ & $\begin{array}{l}\text { Optymalizacja } \\
\text { ustawień urządzenia. }\end{array}$ & $\begin{array}{l}\text { Programowanie, } \\
\text { opieka audiologiczna, } \\
\text { w tym badania } \\
\text { obiektywne. }\end{array}$ & Dzieci. \\
\hline $\begin{array}{l}\text { Patel S. Audiology LEND } \\
\text { trainee. (2011) }\end{array}$ & $\begin{array}{l}\text { Podczas sesji audiolog } \\
\text { wprowadza zmiany } \\
\text { w ustawieniach urządzenia, } \\
\text { dostosowując je do potrzeb } \\
\text { pacjenta, uwzględniając przy } \\
\text { tym jego komfort słyszenia. }\end{array}$ & Satysfakcja pacjenta. & $\begin{array}{l}\text { Programowanie } \\
\text { procesora mowy. }\end{array}$ & $\begin{array}{l}\text { Osoby dorosłe } \\
\text { z niedosłuchem } \\
\text { postlingwalnym. }\end{array}$ \\
\hline $\begin{array}{l}\text { Baudhuin J, Cadieux J, } \\
\text { Firszt JB. Optimization } \\
\text { of programming } \\
\text { parameters in children } \\
\text { with the advanced } \\
\text { bionics cochlear } \\
\text { implant. (2012) }\end{array}$ & $\begin{array}{l}\text { Ustawienia parametrów } \\
\text { stymulacji w procesorach } \\
\text { Advanced Bionics obejmują: } \\
\text { ustawienia wartości } \\
\text { progowych (T-levels), poziom } \\
\text { komfortowego słyszenia } \\
\text { (M-levels), zakres dynamiki } \\
\text { (IDR) oraz czułość mikrofonu. } \\
\text { Wartości T-levels reprezentują } \\
\text { minimalne natężenie prądu } \\
\text { potrzebne do wywołania } \\
\text { reakcji akustycznej, wartości } \\
\text { M-levels oznaczają wartości, } \\
\text { dla których słyszenie jest } \\
\text { komfortowe. Do stworzenia } \\
\text { programu w procesorze mowy } \\
\text { konieczne jest ustawienie } \\
\text { tych parametrów dla każdej } \\
\text { aktywnej elektrody. }\end{array}$ & $\begin{array}{l}\text { Optymalizacja } \\
\text { ustawień. }\end{array}$ & $\begin{array}{l}\text { Programowanie } \\
\text { i opieka audiologiczna. }\end{array}$ & $\begin{array}{l}\text { Dzieci w wieku } \\
\text { 7-17 r.ż. }\end{array}$ \\
\hline $\begin{array}{l}\text { Gordon KA, Chaikof } \\
\text { MH, Salloum C. } \\
\text { Toward a method for } \\
\text { programming balanced } \\
\text { bilateral cochlear } \\
\text { implant stimulation } \\
\text { levels in children. } \\
(2004)\end{array}$ & $\begin{array}{l}\text { Parametry stymulacji w Cl są } \\
\text { bardzo zróżnicowane wśród } \\
\text { użytkowników implantów } \\
\text { i muszą być określane dla } \\
\text { każdej elektrody. (Skinner } \\
\text { 1997). } \\
\text { Zarówno minimalne, } \\
\text { jak i maksymalne wartości } \\
\text { stymulacji są często określane } \\
\text { oddzielnie dla każdej elektrody. } \\
\text { Metody behawioralne są } \\
\text { obecnie uznawane za złoty } \\
\text { standard podczas ustawień } \\
\text { poziomów stymulacji, jednak } \\
\text { mogą być one zawodne } \\
\text { w przypadku małych dzieci, } \\
\text { które mają niewielkie } \\
\text { doświadczenie słuchowe. }\end{array}$ & $\begin{array}{l}\text { Zrównoważony } \\
\text { poziom stymulacji } \\
\text { u dzieci } \\
\text { korzystających ze } \\
\text { stymulacji bilateralnej. }\end{array}$ & $\begin{array}{l}\text { Programowanie } \\
\text { procesora mowy, } \\
\text { opieka audiologiczna } \\
\text { (metody obiektywne } \\
\text { i behawioralne). }\end{array}$ & $\begin{array}{l}\text { Dzieci w wieku } \\
5-13 \text { r.ż., } \\
\text { korzystające } \\
\text { ze stymulacji } \\
\text { bilateralnej. }\end{array}$ \\
\hline
\end{tabular}




\begin{tabular}{|c|c|c|c|c|}
\hline Autorzy & Definicja & Cel & Zakres działania & Grupa pacjentów \\
\hline $\begin{array}{l}\text { Spivak LG, Chute PM. } \\
\text { Programming the } \\
\text { cochlear implant based } \\
\text { on electrical acoustic } \\
\text { reflex thresholds: } \\
\text { patient performance. } \\
\text { (1994) }\end{array}$ & $\begin{array}{l}\text { Mapy tworzone są na } \\
\text { podstawie wartości progu } \\
\text { słyszenia oraz poziomu } \\
\text { komfortowego słyszenia } \\
\text { na podstawie pomiarów } \\
\text { psychofizycznych dla każdej } \\
\text { aktywnej elektrody. }\end{array}$ & $\begin{array}{l}\text { Ustawienie } \\
\text { komfortowego } \\
\text { poziomu, który } \\
\text { zapewni optymalne } \\
\text { słyszenie. }\end{array}$ & $\begin{array}{l}\text { Programowanie } \\
\text { i opieka audiologiczna }\end{array}$ & $\begin{array}{l}\text { Dorośli użytkownicy } \\
\text { Nucleus } 22 .\end{array}$ \\
\hline $\begin{array}{l}\text { Vaerenberg B, De } \\
\text { Ceulaer G, Szlávik Z. } \\
\text { Setting and reaching } \\
\text { targets with computer- } \\
\text { assisted cochlear } \\
\text { implant fitting. (2014) }\end{array}$ & $\begin{array}{l}\text { Znalezienie optymalnych dla } \\
\text { pacjenta wartości stymulacji } \\
\text { nazywane jest fittingiem. } \\
\text { Możliwe to jest dzięki } \\
\text { zastosowaniu odpowiedniego } \\
\text { oprogramowania i interfejsu } \\
\text { oraz na podstawie reakcji } \\
\text { pacjenta. }\end{array}$ & $\begin{array}{l}\text { Ustawienie } \\
\text { parametrów } \\
\text { stymulacji w taki } \\
\text { sposób, by zapewniały } \\
\text { pacjentowi optymalne } \\
\text { rozumienie mowy. }\end{array}$ & $\begin{array}{l}\text { Programowanie } \\
\text { i opieka audilogiczna. }\end{array}$ & Dzieci i dorośli. \\
\hline $\begin{array}{l}\text { Mosca F, Grassia R, } \\
\text { Leone CA. Longitudinal } \\
\text { variations in fitting } \\
\text { parameters for adult } \\
\text { cochlear implant } \\
\text { recipients. (2014) }\end{array}$ & $\begin{array}{l}\text { Procedura dopasowania } \\
\text { implantu ślimakowego } \\
\text { obejmuje ustawienie } \\
\text { odpowiednich poziomów } \\
\text { stymulacji elektrycznej dla } \\
\text { każdego kanału. Zawiera ona } \\
\text { pomiar wartości progowych, } \\
\text { dla których pojawiają się } \\
\text { wrażenia słuchowe (T-levels), } \\
\text { oraz poziomu komfortowego } \\
\text { słyszenia (C-levels). }\end{array}$ & Satysfakcja pacjenta. & $\begin{array}{l}\text { Programowanie } \\
\text { i opieka audiologiczna. }\end{array}$ & $\begin{array}{l}\text { Dorośli w wieku } \\
\text { 18-58 lat. }\end{array}$ \\
\hline $\begin{array}{l}\text { Smoorenburg GF. } \\
\text { Hearing Research } \\
\text { Lahoratdries, University } \\
\text { MeJical Center Utrecht } \\
\text { AZU Fitting the cochlear } \\
\text { implant processor } \\
\text { Parametrically using } \\
\text { live-voice stimuli. (2005) }\end{array}$ & $\begin{array}{l}\text { Dopasowanie procesora } \\
\text { dźwięku do progu słyszenia } \\
\text { oraz komfortowego poziomu } \\
\text { głośności danej jednostki jest } \\
\text { bardzo pracochłonne. Ponadto } \\
\text { może być to trudne dla osób } \\
\text { z niewielkim doświadczeniem } \\
\text { słuchowym. }\end{array}$ & $\begin{array}{l}\text { Dyskryminacja } \\
\text { dźwięków mowy. }\end{array}$ & $\begin{array}{l}\text { Programowanie, } \\
\text { opieka audiologiczna } \\
\text { (w tym badania } \\
\text { obiektywne) }\end{array}$ & $\begin{array}{l}\text { Użytkownicy Nucleus } \\
\text { C124M. }\end{array}$ \\
\hline $\begin{array}{l}\text { Franck KH. A Model of } \\
\text { a Nucleus } 24 \text { cochlear } \\
\text { implant fitting protocol } \\
\text { based on the electrically } \\
\text { evoked whole nerve } \\
\text { action potential (2002). }\end{array}$ & $\begin{array}{l}\text { Dokładne dopasowanie } \\
\text { procesora mowy wymaga } \\
\text { wykonania dwóch pomiarów } \\
\text { na każdej aktywnej } \\
\text { elektrodzie. Urządzenia } \\
\text { firmy Cochlear posiadają } 22 \\
\text { elektrody. Ocena wszystkich } \\
\text { dźwięków może być trudna } \\
\text { dla pacjenta ze względu } \\
\text { na zmęczenie bodźcem. } \\
\text { Dodatkowo percepcja } \\
\text { dźwięków zmienia się wraz } \\
\text { z korzystaniem z implantu. } \\
\text { Dlatego konieczne jest } \\
\text { powtarzanie psychofizycznej } \\
\text { oceny dźwięków. }\end{array}$ & Satysfakcja pacjenta. & $\begin{array}{l}\text { Programowanie } \\
\text { i opieka audiologiczna. }\end{array}$ & $\begin{array}{l}\text { Użytkownicy } \\
\text { implantu } \\
\text { ślimakowego. }\end{array}$ \\
\hline \multicolumn{5}{|c|}{ Podejście centralne } \\
\hline $\begin{array}{l}\text { Legrand P, Bourgeois- } \\
\text { Republique C, Pe'an V. } \\
\text { Interactive evolution } \\
\text { for cochlear implants } \\
\text { fitting. (2007) }\end{array}$ & $\begin{array}{l}\text { Po tym, jak niesłyszący pacjent } \\
\text { zostanie poddany operacji } \\
\text { wszczepienia implantu, } \\
\text { specjalista zajmujący się } \\
\text { dopasowywaniem procesora } \\
\text { mowy musi poświęcić } \\
\text { wiele godzin na precyzyjne } \\
\text { dopasowanie implantu do } \\
\text { potrzeb pacjenta. }\end{array}$ & $\begin{array}{l}\text { Optymalizacja } \\
\text { parametrów } \\
\text { urządzenia oraz } \\
\text { przystosowanie CUN } \\
\text { do nowych danych. }\end{array}$ & $\begin{array}{l}\text { Programowanie } \\
\text { procesora mowy. }\end{array}$ & Brak danych. \\
\hline
\end{tabular}


Pieczykolan A i wsp.: Dopasowanie systemu implantu ślimakowego...

\begin{tabular}{|c|c|c|c|c|}
\hline Autorzy & Definicja & Cel & Zakres działania & Grupa pacjentów \\
\hline $\begin{array}{l}\text { Cooper H, Craddock L. } \\
\text { Cochlear implants: } \\
\text { a practical guide. (2006) }\end{array}$ & $\begin{array}{l}\text { Programowanie procesora jest } \\
\text { wykonywane indywidualnie } \\
\text { dla każdego pacjenta } \\
\text { i zazwyczaj dokonywane jest } \\
\text { na każdej kolejnej wizycie. } \\
\text { Poszczególne programy } \\
\text { zapisywane są w procesorze } \\
\text { mowy do używania przez } \\
\text { pacjenta. Pierwsze programy } \\
\text { tworzone są podczas } \\
\text { aktywacji. Audiolog ma za } \\
\text { zadanie wybrać odpowiednią } \\
\text { strategię kodowania sygnału, } \\
\text { liczbę aktywnych kanałów, } \\
\text { szybkość stymulacji oraz jej } \\
\text { model. }\end{array}$ & Satysfakcja pacjenta. & $\begin{array}{l}\text { Programowanie } \\
\text { procesora mowy, } \\
\text { opieka audiologiczna } \\
\text { i rehablitacja pacjenta } \\
\text { z Cl. }\end{array}$ & Dorośli i dzieci. \\
\hline $\begin{array}{l}\text { Govaerts PJ, Vaerenberg } \\
\text { B, De Ceulaer G. } \\
\text { Development of } \\
\text { a software tool using } \\
\text { deterministic logic } \\
\text { for the optimization } \\
\text { of cochlear implant } \\
\text { processor programming. } \\
(2010)\end{array}$ & $\begin{array}{l}\text { Po operacji wszczepienia } \\
\text { implantu procesor dźwięku } \\
\text { musi być odpowiednio } \\
\text { zaprogramowany } \\
\text { i dostosowany do } \\
\text { indywidualnych potrzeb } \\
\text { pacjenta. Zbiór wartości } \\
\text { pobudzenia zapewniających } \\
\text { słyszenie nazywany jest MAPA. } \\
\text { Ustawienie możliwe jest dzięki } \\
\text { zastosowaniu odpowiedniego } \\
\text { oprogramowania i sprzętu } \\
\text { podłączonego do procesora. } \\
\text { Program tworzy się na } \\
\text { podstawie wyników badań } \\
\text { behawioralnych użytkownika } \\
\text { Cl. }\end{array}$ & $\begin{array}{l}\text { Celem jest ustawienie } \\
\text { parametrów } \\
\text { stymulacji } \\
\text { elektrycznej, które } \\
\text { zapewnią optymalną } \\
\text { percepcję dźwięku. }\end{array}$ & $\begin{array}{l}\text { Programowanie, } \\
\text { opieka audiologiczna, } \\
\text { rehabilitacja (test } \\
\text { ASSE). }\end{array}$ & Brak danych. \\
\hline $\begin{array}{l}\text { Hodges AV, Balkany } \\
\text { TJ, Ruth RA. Electrical } \\
\text { middle ear muscle } \\
\text { reflex: use in cochlear } \\
\text { implant programming. } \\
\text { (1997) }\end{array}$ & $\begin{array}{l}\text { Programowanie } \\
\text { wielokanałowego implantu } \\
\text { ślimakowego obejmuje } \\
\text { także pomiar odruchu } \\
\text { strzemiączkowego } \\
\text { wywołanego elektrycznie } \\
\text { (ESRT), zazwyczaj jest to } \\
\text { trudne do wykonania u małych } \\
\text { prelingwalnych dzieci. }\end{array}$ & Satysfakcja pacjenta. & $\begin{array}{l}\text { Programowanie } \\
\text { procesora, opieka } \\
\text { audiologiczna } \\
\text { (badania obiektywne). }\end{array}$ & $\begin{array}{l}\text { Osoby dorosłe } \\
\text { z niedosłuchem } \\
\text { postlingwalnym. }\end{array}$ \\
\hline \multicolumn{5}{|c|}{ Podejście funkcjonalne } \\
\hline $\begin{array}{l}\text { Metselaar M, Maat B, } \\
\text { Verschuure } \mathrm{H} \text {. } \\
\text { Comparison of speech } \\
\text { intelligibility in quiet } \\
\text { and in noise after } \\
\text { hearing aid fitting } \\
\text { according to a purely } \\
\text { prescriptive and } \\
\text { a comparative fitting } \\
\text { procedure. (2008) }\end{array}$ & $\begin{array}{l}\text { Procedurę dopasowania } \\
\text { podzielić można na dwie fazy: } \\
\text { 1) wybór odpowiedniego } \\
\text { urządzenia; } \\
\text { 2) proces dostrajania. } \\
\text { Ocena korzyści może być } \\
\text { przeprowadzona na każdym } \\
\text { etapie. }\end{array}$ & Satysfakcja pacjenta. & $\begin{array}{l}\text { Programowanie, } \\
\text { opieka audiologiczna, } \\
\text { kwestionariusze } \\
\text { satysfakcji, wywiady, } \\
\text { rehabilitacja. }\end{array}$ & $\begin{array}{l}\text { Osoby dorosłe } \\
\text { w wieku 29-95 lat. }\end{array}$ \\
\hline $\begin{array}{l}\text { Waltzman SB, Roland JT. } \\
\text { Cochlear implants. } \\
(2005)\end{array}$ & $\begin{array}{l}\text { Istotny wpływ na wydajność } \\
\text { procesora mowy ma sposób, } \\
\text { w jaki jest on programowany. } \\
\text { Behawioralne reakcje } \\
\text { dorosłych użytkowników Cl są } \\
\text { wystarczające do ustawienia } \\
\text { wartości progowych i poziomu } \\
\text { komfortowego słyszenia } \\
\text { u większości pacjentów. }\end{array}$ & $\begin{array}{l}\text { Rozwój językowy } \\
\text { u dzieci i komunikacja. }\end{array}$ & $\begin{array}{l}\text { Programowanie, } \\
\text { opieka audiologiczna, } \\
\text { rehabilitacja } \\
\text { i edukacja. }\end{array}$ & $\begin{array}{l}\text { Dzieci poniżej } 1 \text { r.ż., } \\
\text { z dwustronnym } \\
\text { ubytkiem słuchu } \\
\text { - znacznym lub } \\
\text { głębokim. }\end{array}$ \\
\hline
\end{tabular}




\begin{tabular}{|c|c|c|c|c|}
\hline Autorzy & Definicja & Cel & Zakres działania & Grupa pacjentów \\
\hline $\begin{array}{l}\text { Clinical guidelines } \\
\text { for adult cochlear } \\
\text { implantation } \\
\text { Department of Health, } \\
\text { State of Western } \\
\text { Australia. (2011) }\end{array}$ & $\begin{array}{l}\text { Procesory mowy powinny } \\
\text { być programowanie } \\
\text { przez doświadczonych } \\
\text { specjalistów, którzy zostali } \\
\text { do tego odpowiednio } \\
\text { przygotowani, w przypadku } \\
\text { mniej doświadczonych } \\
\text { audiologów konieczny jest } \\
\text { nadzór. Członkowie zespołu } \\
\text { przed podłączeniem powinni } \\
\text { być świadomi wszelkich } \\
\text { kwestii chirurgicznych } \\
\text { związanych z operacją. } \\
\text { Po aktywacji urządzenia } \\
\text { przeprowadza się badanie } \\
\text { impedancji elektrod, w celu } \\
\text { sprawdzenia funkcjonowania } \\
\text { części wewnętrznej. Każde } \\
\text { urządzenie powinno mieć } \\
17 \text { sesji programowania } \\
\text { z uwzględnieniem zalecanych } \\
\text { przez producenta procedur } \\
\text { oraz preferencji i korzyści } \\
\text { pacjenta. }\end{array}$ & Satysfakcja pacjenta. & $\begin{array}{l}\text { Programowanie, } \\
\text { opieka audiologiczna } \\
\text { i rehabilitacja } \\
\text { (wykrywanie dźwięku, } \\
\text { w tym również } \\
\text { jego lokalizacja, } \\
\text { test przestrzenny, } \\
\text { słuchowe rozróżnianie, } \\
\text { ćwiczenia głosu } \\
\text { i rozumienia mowy). }\end{array}$ & Dorośli. \\
\hline $\begin{array}{l}\text { Lorens A. Model } \\
\text { rehabilitacji } \\
\text { audiologicznej } \\
\text { po wszczepieniu } \\
\text { implantu ślimakowego } \\
\text { opracowany } \\
\text { na podstawie } \\
\text { Międzynarodowej } \\
\text { Klasyfikacji } \\
\text { Funkcjonowania, } \\
\text { Niepełnosprawności } \\
\text { i Zdrowia (ICF). (2014) }\end{array}$ & $\begin{array}{l}\text { Zgodnie z najnowszymi } \\
\text { zaleceniami organizacji } \\
\text { audiologicznych } \\
\text { opieka pooperacyjna po } \\
\text { wszczepieniu implantu } \\
\text { ślimakowego powinna być } \\
\text { oparta na najnowszym modelu } \\
\text { funkcjonalnym } \\
\text { niepełnosprawności, który } \\
\text { został stworzony } \\
\text { na potrzeby Międzynarodowej } \\
\text { Klasyfikacji Funkcjonowania, } \\
\text { Niepełnosprawności i Zdrowia. } \\
\text { Model ten zakłada, że } \\
\text { niepełnosprawność jest to } \\
\text { termin całościowy, obejmujący } \\
\text { uszkodzenia, ograniczenia } \\
\text { aktywności oraz ograniczenia } \\
\text { uczestnictwa. }\end{array}$ & $\begin{array}{l}\text { Ograniczenie } \\
\text { wywołanych } \\
\text { niedosłuchem } \\
\text { deficytów w funkcjach } \\
\text { struktur ciała } \\
\text { ludzkiego, aktywności } \\
\text { i uczestnictwie. }\end{array}$ & $\begin{array}{l}\text { Programowanie, } \\
\text { opieka audiologiczna, } \\
\text { rehabilitacja } \\
\text { i edukacja. }\end{array}$ & Dzieci i dorośli. \\
\hline
\end{tabular}

\section{Wyniki}

Po dogłębnej analizie zakwalifikowanych do przeglądu artykułów sporządzono wykaz opisanych procedur dopasowania procesora mowy, biorąc pod uwagę ich cel, zakres działania oraz grupy docelowe objęte procesem dopasowania (tabela 1).

Proces dopasowania systemu implantu ślimakowego w literaturze, choć zawsze oparty na założeniach teoretycznych przedstawionych we wstępie, rozumiany jest różnorodnie. Zdaniem 12 autorów dopasowanie procesora jest to ustawienie minimalnych oraz maksymalnych poziomów stymulacji zakończeń nerwu słuchowego na podstawie wyników badań psychofizycznych, pomiarów obiektywnych i badań audiologicznych. Jest to tzw. podejście peryferyjne $[16,21,24,31-37]$.

Przykładem takiego podejścia jest procedura opisywana przez Boyda, gdzie głównym zadaniem podczas programowania procesora mowy jest dobór zakresu dynamiki pobudzenia elektrycznego dla każdej elektrody znajdującej się w ślimaku [25]. Inaczej ujmując - uzyskanie komfortowego poziomu głośności na każdej z aktywnych elektrod. Na proces dopasowania składają się zazwyczaj pomiary psychofizyczne elektrycznego progu słyszenia oraz określenie maksymalnego poziomu tolerancji. Możliwe jest to dzięki zastosowaniu krótkich impulsów generowanych przez specjalistyczne oprogramowanie komputerowe. Programowanie procesora obejmuje także inne pomiary i badania na kolejnych etapach, tj. badanie audiometrii tonalnej w wolnym polu w zakresie $500-4000 \mathrm{~Hz}$ oraz badanie rozumienia mowy w warunku odsłuchu przez system implantu [24].

Podobne ujęcie prezentuje także Mosca. Zdaniem tego autora procedura dopasowania implantu ślimakowego obejmuje ustawienie odpowiednich poziomów stymulacji elektrycznej dla każdego kanału (elektrody). Obejmuje ona pomiar wartości progowych, dla których pojawiają się wrażenia słuchowe (T-levels), oraz poziomu komfortowego słyszenia (C-levels) [35].

W swojej pracy Gordon jako podstawową metodę dopasowania systemu implantu przedstawia postępowanie oparte 
na wynikach pomiarów obiektywnych czynnościowych potencjałów wywołanych (ang. Evoked Compound Action Potentials, ECAP) nerwu słuchowego. Badanie to pokazuje, dla jakich poziomów stymulacji pojawiają się potencjały czynnościowe nerwu słuchowego [36].

Uzupełnieniem procedury dopasowania może być także badanie odruchu z mięśnia strzemiączkowego wywołanego elektrycznie (ang. Electrically Evoked Stapedius Responses Thresholds, ESRT). W badaniach wykazano istnienie wysokiej korelacji pomiędzy progiem odruchu a wartościami komfortowego słyszenia (MCL). Dzięki temu pomiarowi specjalista zajmujący się ustawieniem systemu implantu ślimakowego może określić optymalny dla danego pacjenta poziom stymulacji elektrycznej $[20,28,38]$.

Z kolei część autorów podczas dopasowania procesora mowy bierze pod uwagę plastyczność ośrodkowego układu nerwowego (OUN), uwzględniając tym samym zmiany zachodzące w nim wraz z upływem czasu - jest to tzw. podejście centralne $[10,29,39]$. Według Legranda Æ dopasowanie implantu jest czasochłonne, potrzeba na to wielu godzin, a nawet miesięcy. Proces dopasowania składa się z dwóch głównych etapów: odpowiedniego dopasowania parametrów stymulacji oraz „nauki słuchania” przez implant [10]. Cooper i Craddock opisują programowanie implantu jako proces dostosowany indywidualnie do każdego pacjenta. Ważnym elementem, co podkreślają autorzy, jest również rehabilitacja słuchowa [29].

Wśród specjalistów zajmujących się dopasowaniem systemu implantu ślimakowego można także wyodrębnić tzw. podejście funkcjonalne bądź inaczej globalne. Dopasowanie systemu implantu w tym przypadku rozumiane jest jako postępowanie ukierunkowane na zminimalizowanie skutków niepełnosprawności pacjenta w różnych sytuacjach życiowych $[9,22,26,40]$.

Zdaniem Lorensa [22] opieka pooperacyjna po wszczepieniu implantu ślimakowego powinna być oparta na najnowszym modelu funkcjonalnym niepełnosprawności, który został stworzony na potrzeby Międzynarodowej Klasyfikacji Funkcjonowania, Niepełnosprawności i Zdrowia ICF. Model ten zakłada, że niepełnosprawność jest to termin całościowy, obejmujący uszkodzenia, ograniczenia aktywności oraz ograniczenia uczestnictwa.

Według tej koncepcji dobór odpowiednich strategii pomocowych dokonywany jest $\mathrm{z}$ wykorzystaniem aktualnej wiedzy o niepełnosprawności. Według ICF, uszkodzenie to problem w funkcjonowaniu bądź strukturze ciała. Ograniczenie aktywności to trudności, jakie napotyka dana jednostka podczas wykonywania działań lub zadań, natomiast ograniczenie uczestnictwa jest to problem zaangażowania się jednostki w określone sytuacje życiowe. Zgodnie z ICF, dopasowanie systemu implantu to postępowanie ukierunkowane na rozwiązanie problemu (ang. a problem-solving excercise), mające na celu ograniczenie negatywnych skutków niedosłuchu poprzez stworzenie warunków do aktywności i przywrócenie pełnego uczestniczenia w sytuacjach życiowych. Niekwestionowaną podstawą dopasowania systemu implantu jest dobór odpowiednich parametrów stymulacji elektrycznej w celu kompensacji utraconych w konsekwencji niedosłuchu funkcji słuchowych $[41,42]$. Takie rozumienie procesu dopasowania systemu implantu wydaje się najbardziej zbieżne z funkcjonalnym modelem niepełnosprawności opracowanym na potrzeby ICF [22].

Dodatkowo autorzy podkreślają, jak wielkie znaczenie $\mathrm{w}$ procesie dopasowania systemu implantu ślimakowego ma wiedza interdyscyplinarna [6,9]. W skład zespołu zajmującego się pacjentami implantowanymi powinni wchodzić specjaliści z różnych dziedzin, m.in. lekarze otolaryngolodzy, audiolodzy, logopedzi, psycholodzy, osoby dopasowujące parametry symulacji (inżynierowie kliniczni, audiolodzy) oraz pracownicy administracyjni - zajmujący się sprawami organizacyjnymi, np. uzgadnianiem terminów wizyt.

\section{Dyskusja}

Analizując przedstawione powyżej metody dopasowania parametrów stymulacji systemu implantu ślimakowego, można dostrzec różnice nie tylko w samym rozumieniu pojęcia dopasowania systemu implantu ślimakowego, lecz także w zakresie podjętych działań. Wszystkie te różnice wynikać mogą z różnych grup docelowych - inne postępowanie preferują autorzy skupiający się na dopasowaniu procesora mowy u dzieci $[24,32,34]$, a odmienne specjaliści zajmujący się doborem parametrów stymulacji u osób dorosłych $[25,31,43,44]$. Warto podkreślić również, że $\mathrm{z}$ biegiem lat oraz rosnącym doświadczeniem $\mathrm{w}$ dziedzinie implantów zmianom ulega podejście autorów do pojęcia niepełnosprawności oraz procesu dopasowania.

Zdaniem większości specjalistów proces dopasowania systemu implantu ślimakowego ma charakter peryferyjny (ok. $60 \%$ autorów, których artykuły wykorzystano w niniejszej pracy). Oznacza to, że w tym przypadku główny nacisk podczas ustawiania implantu ślimakowego kładzie się na odpowiedni dobór parametrów psychofizycznych, tj. zakresu dynamiki pobudzenia, progu elektrycznego słyszenia czy poziomu komfortowego słyszenia. Celem takich działań była zazwyczaj szeroko pojęta satysfakcja pacjenta bądź zdolność do dyskryminacji dźwięków mowy i otoczenia. W grupie osób, którym dedykowane są te procedury, znajdują się zarówno małe, prelingwalne dzieci, jak i postlingwalni dorośli, korzystający z implantów ślimakowych [17,28].

Około $20 \%$ prezentowanych w niniejszej pracy definicji dotyczy podejścia centralnego. Specjaliści zajmujący się doborem parametrów stymulacji podkreślają, jak ważnym elementem w procesie dopasowania systemu implantu jest rehabilitacja dostosowana do potrzeb i możliwości pacjenta implantowanego. Ważnym aspektem prezentowanym w tym podejściu jest także plastyczność OUN, czyli uwzględnianie zmian zachodzących w mózgu na skutek stymulacji elektrycznej nerwu słuchowego [18,34,35].

Z kolei w pozostałych $20 \%$ publikacji zostało przedstawione podejście funkcjonalne. Jego zwolennicy podkreślają, że wpływ na skuteczność procesu dopasowania mają także inne czynniki. Według najnowszego podejścia do niepełnosprawności, niepełnosprawność słuchowa to nie tylko problem w odbiorze mowy i dźwięków, lecz także szereg innych konsekwencji zarówno psychologicznych, jak i społecznych $[27,29,30]$. 
Publikacje dotyczące trzech koncepcji dopasowania systemu implantu ślimakowego

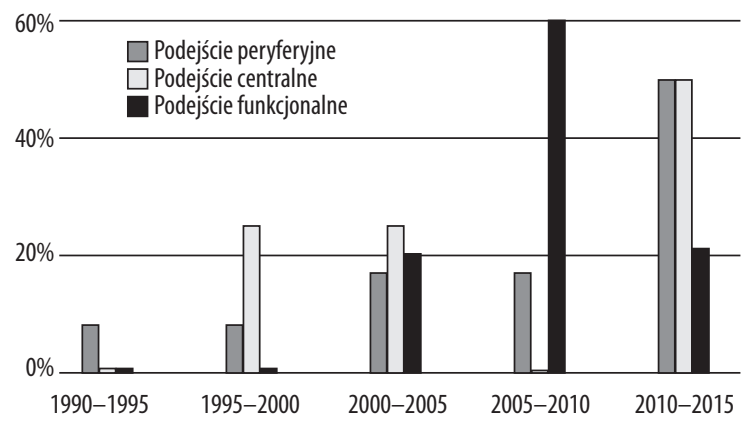

Rycina 3. Rozkład procentowy publikacji dotyczących dopasowania systemów implantów ślimakowych z uwzględnieniem wszystkich trzech koncepcji w latach 1990-2015

Figure 3. The percentage of publication about fitting of cochlear implant system described in the literature were included. All of the three fitting conceptions in the years 1990-2015

Warto podkreślić, że z biegiem lat oraz zwiększającym się doświadczeniem w dziedzinie implantów zmianie uległo rozumienie procedury dopasowania, co zostało przedstawione na rycinie 3. Początkowo dominowało podejście peryferyjne, w latach 1995-2000 podejście centralne, natomiast po stworzeniu Międzynarodowej Klasyfikacji Funkcjonowania, Niepełnosprawności i Zdrowia w literaturze zaczęły pojawiać się także pozycje dotyczące podejścia funkcjonalnego [29].

\section{Wnioski}

Pomimo wieloletniej praktyki w leczeniu osób niedosłyszących i niesłyszących nie udało się stworzyć jednolitego modelu opieki nad pacjentem. W zależności od przyjętych w poszczególnych ośrodkach kryteriów działania terapeutyczne różnią się nie tylko odmiennym sposobem postrzegania dopasowania systemu implantu ślimakowego, lecz także zakresem działań wchodzących w jego skład. Istnieją jednak także pewne podobieństwa, jak na przykład pomiar impedancji elektrycznej, ustalanie zakresu dynamiki pobudzenia czy robienie kontrolnych badań audiometrycznych [24].

Dopasowanie systemu implantu ślimakowego zgodnie $\mathrm{z}$ modelem funkcjonalnym jest podejściem najnowszym, zgodnym z założeniami zawartymi w Międzynarodowej Klasyfikacji Funkcjonowania, Niepełnosprawności i Zdrowia. Wydaje się ono najpełniej uwzględniać indywidualne potrzeby pacjenta implantowanego. Dopasowanie systemu implantu rozumiane tu jest jako postępowanie ukierunkowane na rozwiązanie problemu, mające na celu ograniczenie negatywnych skutków niepełnosprawności słuchowej.

Publikacja powstała $w$ zwiazku $z$ realizacja projektu pn. „Zintegrowany system narzędzi do diagnostyki i telerehabilitacji schorzeń narząów zmysłów (słuchu, wzroku, mowy, równowagi, smaku, powonienia)" INNOSENSE, wspólfinansowanego przez Narodowe Centrum Badań i Rozwoju w ramach Programu STRATEGMED.

Projekt zostat sfinansowany ze środków Narodowego Centrum Nauki przyznanych na podstawie decyzji numer DEC-2013/09/B/ ST7/04213.

\section{Piśmiennictwo:}

1. Cochlear Implants NIDCD, https://www.nidcd.nih.gov/health/ cochlear-implants.

2. Skarżyński H, Piotrowska A, Lorens A. Wszczepy ślimakowe. W: Śliwińska-Kowalska M, red. Audiologia kliniczna. Mediton, 2005; 429-42.

3. House WF, Urban J. Long term results of electrode implantation and electronic stimulation of the cochlea in man. Ann Otol Rhinol Laryngol, 1973; 82(4): 504-17.

4. Chouard CH, Macleod P. Implantation of multiple intracochlear electrodes for rehabilitation of total deafness: preliminary report. Laryngoscope, 1976; 86(11): 1743-51.

6. Burian K, Hochamir-Desoyer IJ, Eisenwort B. The Vienna cochlear implant program. Otolaryngol Clin North Am, 1986; $19 ; 313-28$.

6. Piotrowska A, Lorens A, Szuchnik J, Wojewódzka B, Kosmalowa J, Skarżyński H. Procedura przedoperacyjna kwalifikacji do wszczepienia implantu ślimakowego stosowana w Instytucie Fizjologii i Patologii Słuchu w Warszawie. Audiofonologia, 2001; 20: 43-50.

7. Kiefer J, Ilberg C von, Reimer B, Knecht R, Gall V, Diller G i wsp. Results of cochlear implantation in patients with severe to profound hearing loss - implications for patient selection. Audiology, 1998; 37(6): 382-95.

8. Szkiełkowska A, Skarżyński H, Piotrowska A, Lorens A, Szuchnik J. Postępowanie u dzieci ze wszczepami ślimakowymi. Otolaryngol Pol, 2008; 7(3): 121-28.
9. Clinical Guidelines for Adult Cochlear Implantation. Department of Health. State of Western Australia, 2011.

10. Legrand P, Péan V, Harboun-Cohen E, Levy-Vehel J, Frachet $\mathrm{B}$, Lutton $\mathrm{E}$ i wsp. Interactive evolution for cochlear implants fitting. Genet Program Evolvable Mach, 2007; 8(4): 319-54.

11. Ilberg C von, Kiefer J, Tillein J, Pfenningdorff T, Hartmann R, Stürzebecher E i wsp. Electric-acoustic stimulation of the auditory system New technology for severe hearing loss. ORL J Oto-Rhino-Laryngol Its Relat Spec, 1999; 61(6): 334-40.

12. Lorens A, Polak M, Piotrowska A, Skarzynski H. Outcomes of treatment of partial deafness with cochlear implantation: a DUET study. Laryngoscope, 2008; 118(2): 288-94.

13. Skarzynski H, Lorens A. Electric acoustic stimulation in children. Adv Otorhinolaryngol, 2010; 67: 135-43.

14. Pyschny V, Landwehr M, Hahn M, Lang-Roth R, Walger M, Meister H. Head shadow, squelch, and summation effects with an energetic or informational masker in bilateral and bimodal CI users. J Speech Lang Hear Res JSLHR, 2014; 57(5): 1942-60.

15. Sheffield SW, Haynes DS, Wanna GB, Labadie RF, Gifford RH. Availability of binaural cues for pediatric bilateral cochlear implant recipients. J Am Acad Audiol, 2015; 26(3): 289-98.

16. Gordon KA, Chaikof MH, Salloum C, Goulding G, Papsin B. Toward a method for programming balanced bilateral cochlear implant stimulation levels in children. Cochlear Implants Int, 2012; 13(4): 220-27. 
17. Tokita J, Dunn C, Hansen MR. Cochlear implantation and single sided deafness. Curr Opin Otolaryngol Head Neck Surg, 2014; 22(5): 353-58.

18. Henkin Y, Kaplan-Neeman R, Muchnik C, Kronenberg J, Hildesheimer M. Changes over time in electrical stimulation levels and electrode impedance values in children using the Nucleus 24M cochlear implant. Int J Pediatr Otorhinolaryngol, 2003; 67(8): 873-80.

19. Zadrożniak M, Szymański M, Siwiec H, Broda T. Impedance changes in cochlear implant users. Otolaryngol Pol, 2011; 65(3): 214-17.

20. Lorens A, Piotrowska A, Wąsowski A, Walkowiak A, Skarżyński H i wsp. Objective method of paediatric cochlear implant system fitting. New Med, 2004.

21. Zwolan TA, O'Sullivan MB, Fink NE, Niparko JK, Team CI i wsp. Electric charge requirements of pediatric cochlear implant recipients enrolled in the childhood development after cochlear implantation study. Otol Neurotol, 2008; 29(2): 143-48.

22. Lorens A. Model rehabilitacji audiologicznej po wszczepieniu implantu ślimakowego opracowany na podstawie Międzynarodowej Klasyfikacji Funkcjonowania, Niepełnosprawności i Zdrowia (ICF). Nowa Audiofonol, 2014; 3(5): 77-90.

23. Implanty ślimakowe - zasada działania | kardiologia inwazyjna | otolaryngologia |, http://www.kardiologiainwazyjna.pl/mod/ archiwum/8367,implanty,\%C5\%9Blimakowe,zasada.html.

24. Vaerenberg B, Smits C, De Ceulaer G, Zir E, Harman S, Jaspers $\mathrm{N}$ i wsp. Cochlear implant programming: a global survey on the state of the art. ScientificWorldJournal, 2014; 2014: 501738.

25. Boyd PJ. Effects of programming threshold and maplaw settings on acoustic thresholds and speech discrimination with the MED-EL COMBI 40+ cochlear implant. Ear Hear, 2006; 27(6): 608-18.

26. Metselaar M, Maat B, Krijnen P, Verschuure H, Dreschler W, Feenstra L. Comparison of speech intelligibility in quiet and in noise after hearing aid fitting according to a purely prescriptive and a comparative fitting procedure. Eur Arch Otorhinolaryngol, 2008; 265(9): 1113-20.

27. Skinner MW, Holden LK, Holden TA, Demorest ME. Comparison of two methods for selecting minimum stimulation levels used in programming the Nucleus 22 cochlear implant. J Speech Lang Hear Res, 1999; 42(4): 814-28.

28. Hodges AV, Balkany TJ, Ruth RA, Lambert PR, Dolan-Ash S, Schloffman JJ. Electrical middle ear muscle reflex: use in cochlear implant programming. Otolaryngol Neck Surg, 1997; 117(3): 255-61.

29. Cooper H, Craddock L. Cochlear implants: a practical guide. John Wiley \& Sons, 2006.
30. Smoorenburg GF. Fitting the cochlear implant processor parametrically using live-voice stimuli. Int Congr Ser, 2004; 1273 : 183-86.

31. The Effect of cochlear implant threshold and comfort levels over time Shivani Patel.pdf.

32. Vaerenberg B, De Ceulaer G, Szlávik Z, Mancini P, Buechner A, Govaerts PJ. Setting and reaching targets with computer-assisted cochlear implant fitting. ScientificWorldJournal, 2014; 2014: 646590.

33. Clark JH, Wang N-Y, Riley AW, Carson CM, Meserole RL, Lin FR i wsp. Timing of cochlear implantation and parents' global ratings of children's health and development. Otol Neurotol Off Publ Am Otol Soc Am Neurotol Soc Eur Acad Otol Neurotol, 2012; 33(4): 545-52.

34. Baudhuin J, Cadieux J, Firszt JB, Reeder RM, Maxson JL. Optimization of programming parameters in children with the advanced bionics cochlear implant. J Am Acad Audiol, 2012; 23(5): 302-12.

35. Mosca F, Grassia R, Leone CA. Longitudinal variations in fitting parameters for adult cochlear implant recipients. Acta Otorhinolaryngol Ital, 2014; 34(2): 111-16.

36. Gordon K, Papsin BC, Harrison RV. Programming cochlear implant stimulation levels in infants and children with a combination of objective measures. Int J Audiol, 2004; 43 (Suppl. 1): 28-32.

37. Franck KH. A model of a Nucleus 24 cochlear implant fitting protocol based on the electrically evoked whole nerve action potential. Ear Hear, 2002; 23(1): 67-71.

38. Lorens A, Zgoda M, Obrycka A, Skarżynski H. Fine structure processing improves speech perception as well as objective and subjective benefits in pediatric MED-EL COMBI 40+ users. Int J Pediatr Otorhinolaryngol, 2010; 74(12): 1372-78.

39. Govaerts PJ, Vaerenberg B, De Ceulaer G, Daemers K, De Beukelaer C, Schauwers K. Development of a software tool using deterministic logic for the optimization of cochlear implant processor programming. Otol Neurotol, 2010; 31(6): 908-18.

40. Waltzman SB, Roland JT. Cochlear implantation in children younger than 12 months. Pediatrics, 2005; 116(4): 487-93.

41. WHO | International Classification of Functioning, Disability and Health (ICF), http://www.who.int/classifications/icf/en/.

42. Światowa Organizacja Zdrowia. Międzynarodowa Klasyfikacja Funkcjonowania, Niepełnosprawności i Zdrowia (ICF). Warszawa: Centrum Systemów Informacyjnych Ochrony Zdrowia; 2009.

43. Spivak LG, Chute PM, Popp AL, Parisier SC. Programming the cochlear implant based on electrical acoustic reflex thresholds: patient performance. Laryngoscope, 1994; 104(10): 1225-30.

44. Walkowiak A, Śliwa L, Lorens A. Programowanie procesora implantu ślimakowego w badaniach neuropsychologicznych pacjentów implantowanych. Audiofonologia, 2003; 23: 77-85. 